\title{
ENVIRONMENTAL CONDITIONS IN BROILER MULTI-STAGE SETTER - A CASE STUDY
}

\author{
Ana Carolina de Souza Gigli'; Marta dos Santos Baracho²; Irenilza de Alencar Nääs*; \\ Douglas D'Alessandro Salgado'; Débora Passos Alvarenga ${ }^{2}$ \\ ${ }^{1}$ UNICAMP/FEAGRI - Programa de Pós Graduação em Engenharia Agrícola. \\ ${ }^{2}$ UNICAMP/FEAGRI - Lab. de Conforto Térmico, C.P. 6011 - Campinas, SP - Brasil. \\ *Corresponding author <irenilza@agr.unicamp.br>
}

\begin{abstract}
Production of one day-old chick production is one of the most important segments in the poultry production business. Broiler chicken incubation environment needs to be homogeneous and adequate so hatchability and final product quality are not affected. This research aimed at evaluating environmental conditions inside a multi-stage setter in a commercial hatchery house. The incubator was split into six areas and data loggers placed in the geometric center to register temperature and relative humidity data; carbon dioxide concentration and number of colony forming units (CFU) of fungi were also sampled and analyzed; Kruskal-Wallis non-parametric test was used for statistical analysis; significant differences in temperature and relative humidity distribution inside the incubator $(p<0.05)$ were detected, but no differences were found in $\mathrm{CO}_{2}$ concentrations or CFU distribution inside the incubator $(p>0.05)$. Fungi incidence varied from average to good. Critical points were detected in all areas inside the setter.
\end{abstract}

Key words: poultry, incubation, environment

\section{CONDIÇÕES AMBIENTAIS EM INCUBADORA DE MÚLTIPLO ESTÁGIO: UM ESTUDO DE CASO}

\begin{abstract}
RESUMO: A produção de pintinhos de um dia é um dos segmentos mais importantes da cadeia avícola. O ambiente de incubação de frangos de corte precisa ser homogêneo e adequado de modo a não afetar a eclodibilidade e a qualidade do produto final. Avaliaram-se as condições de ambiência no interior de incubadora de estágio múltiplo durante um lote de produção em incubatório comercial. A incubadora foi dividida em seis quadrantes em cujo centro geométrico foram colocados registradores de valores de temperatura e umidade relativa. A concentração de dióxido de carbono, bem como o número de unidades formadoras de colônias (CFU) de fungos também foram amostradas nos mesmos locais; o teste não paramétrico de Kruskal-Wallis foi utilizado para análise estatística. Foram detectadas diferenças na distribuição de temperatura e umidade relativa no interior da incubadora $(p<0,05)$, mas não foi encontrada diferença na distribuição de $\mathrm{CO}_{2}$ e de $\mathrm{CFU}$ no interior da incubadora $(p>0,05)$. A incidência de fungos variou de média a boa. Pontos críticos foram detectados em todas as áreas dentro da incubadora.

Palavras-chave: avicultura, incubação, ambiência
\end{abstract}

\section{INTRODUCTION}

Brazilian broiler production neared $9 \times 10^{6} \mathrm{t}$ in 2006, and reached $10 \times 10^{6} \mathrm{t}$ in 2007 . This new record resulted from increased both export and domestic consumption. Export of poultry meat was favored indirectly from Avian Influenza affecting several broiler producing areas of the world (USDA, 2005).

Efficiency of one day-old chick production is one of the most important variables in the development of modern poultry industry, and the hatchery house environment directly influences final product quality (Decuypere \& Michels, 1992). Hatching effi- ciency is directly related to environmental and biological ambiance, as well as embryo's physical conditions (Boleli, 2003; Muraroli \& Mendes, 2003; Boerjan, 2006).

Setting off optimum incubation temperatures leads to best hatchability and chick quality (Wilson 1991; Decuypere \& Michels, 1992; French, 1997). Optimum incubation temperature of most avian specied is 37 to $38^{\circ} \mathrm{C}$ and minor deviations negatively impact incubation performance and embryo development (Wilson, 1991). Poor incubation success results from timely combination of either high or low environmental temperature and inadequate relative humidity inside the hatchery (Decuypere \& Michels, 1992), and when 
lack of ventilation affects oxygen renewal (Alda, 2003; MSU, 2004). Embryonic mortality may result from fungi (Aspergillus sp. and Penicillium sp.) contamination during the incubation, and hatchery houses are ideal environments for fungi development - high temperature, high relative humidity and high level of organic material. Adequate fungal control is desirable for biosecurity purposes, and the aerial environment in a hatchery can be classified according to Sadler table (Table 1), which establishes ambient air quality based on mean number of fungi colonies (Tessari et al., 2002).

This research aimed at evaluating ambient temperature and relative humidity conditions, carbon dioxide concentration and fungi colony forming unit incidence inside a multi-stage setter during one flock production in a commercial hatchery, defining hatchery critical points.

\section{MATERIAL AND METHODS}

The experiment was carried out in a commercial hatchery located in Amparo, State of São Paulo,

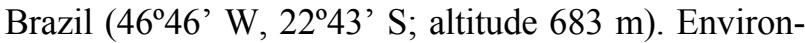
mental conditions (dry bulb temperature - DBT; relative humidity - $\mathrm{RH})$; carbon dioxide $\left(\mathrm{CO}_{2}\right)$ concentration, and number of fungi colony forming units (CFU) were registered inside a broiler multi-stage setter $\left(\mathrm{CASP}^{\circledR} \mathrm{C} \mathrm{Mg}\right.$ 125Re, 124,416 eggs capacity) during one flock production. For the case study, 30,104 Cobb line eggs were used.

Eggs were selected by size and origin, measured, identified and arranged onto the empty traysto compensate heat distribution, i.e., large eggs were placed in known colder regions, while smaller eggs were placed near hotter areas to avoid cold spots. The incubator measured $3.45 \mathrm{~m}$ (front wall) by, $6.97 \mathrm{~m}$ (lateral wall) by $2.67 \mathrm{~m}$ (height) and had 1,296 trays holding 96 eggs each. Incubator's airflow capacity was $2,300 \mathrm{~m}^{3} \mathrm{~h}^{-1}$, and ambient settings were $37.5^{\circ} \mathrm{C}$ and $60 \%$ RH. After 18-day incubation period, eggs were transferred to hatchery chambers (twice a week) replacing hatched eggs.

Table 1 - Sadler microorganisms classification table (Tessari et al., 2002).

\begin{tabular}{lc}
\hline Classification & Mean number of fungi colonies \\
\hline Excellent & 0 \\
Good & $1-3$ \\
Average & $4-6$ \\
Below average & $7-10$ \\
Poor & $11-12$ \\
Very poor & more than 13 \\
\hline
\end{tabular}

The incubator was divided in six areas (Figure 1). Six data loggers (Pacer ${ }^{\circledR}$ HTA 4200) were placed $1 \mathrm{~m}$ above ground in the geometric center of each area. All data loggers were programmed to continuously record data on environmental dry bulb temperature (DBT), RH and wind speed every $45 \mathrm{~min}$. Carbon dioxide concentration was sampled using a portable pump (Accuro Dräger ${ }^{\circledR}$ ) with a short-term $\mathrm{CO}_{2}$ reagent tube $\left(5.0 \times 10^{-2} \mathrm{~mol} \mathrm{~m}^{-3}-13.4 \times 10^{-2} \mathrm{~mol} \mathrm{~m}^{2}\right)$ attached.

Number of fungi (CFU) was determined by the exposition of Petri dishes with Complete Media Culture $(\mathrm{CMC})$ for $15 \mathrm{~min}$ to incubators ambient (Pontecorvo et al., 1953), and latter incubation of Petri dishes at $27^{\circ} \mathrm{C}$ for three days, colonies were then counted and identified according to fungi genus morphology (Silveira, 1968).

A descriptive statistical analysis was applied to the data using the software Minitab ${ }^{\circledR} 15$ (Minitab, Inc., 2006) and not all results present a normal distribution. The Kruskal-Wallis test was then used to evaluate variables' spatial distribution $(\alpha=0.05)$.

\section{RESULTS AND DISCUSSION}

Table 2 shows production data after hatching. The descriptive statistical results of the environmental conditions in each area are presented in Table 3. Differences in DBT distribution on A1 and A2, and also a tendency of lower DBT in these areas were detected; DBT was not distributed homogeneously $(p<0.05)$ (Table 5).

Available hatchery technology should provide good incubation conditions. However, hatchery equipment and machines frequently do not perform as expected given that temperature adjustments in setters and hatchers are not accurate enough to elicit uniform temperature distribution inside the equipment, leading

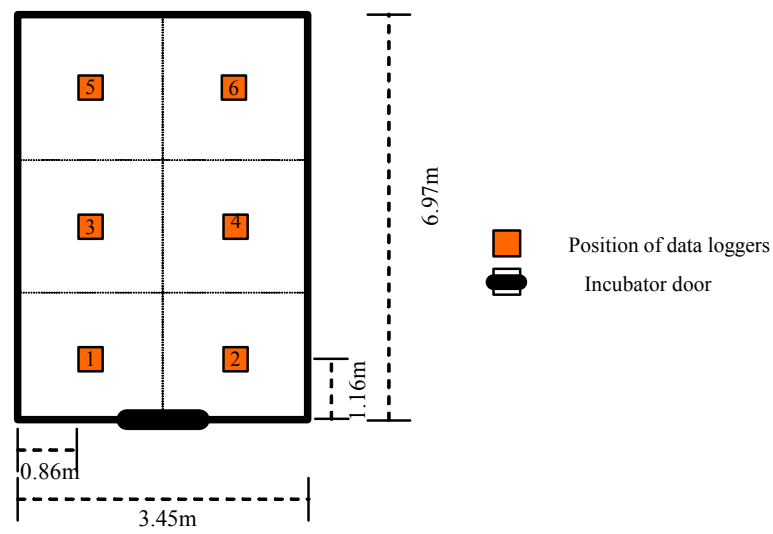

Figure 1 - Division of areas and data loggers' position inside the incubator where the samples were taken. 
Table 2 - Production data on the studied flock incubated in the multi-setter.

\begin{tabular}{lcc}
\hline Production data & Quantity & Percentage (\%) \\
\hline Number of incubated eggs & 30,104 & - \\
Average weight of eggs $(\mathrm{g})$ & 69.8 & - \\
Hatchability & 27,405 & 91.0 \\
Chick mortality & 309 & 1.02 \\
Prime chicks & 27,000 & 86.9 \\
Inferior chicks & 96 & 0.3 \\
\hline
\end{tabular}

to poor hatchability (Bramwell, 2002). This information was herein confirmed. Temperature values lower than those recommended by literature $\left(37\right.$ to $\left.38^{\circ} \mathrm{C}\right)$ were actually recorded close to incubator's doors (A1 and A2; Figure 1), and thus considered critical points for temperature setting.

Poor or unbalanced temperature distribution and sudden changes affect embryos development and depress hatchability (French, 1997; Wilson, 1991). Because during the multi-stage setter management the machine's door is opened rather frequently, embryos incubated near these areas are exposed to uneven temperatures, which may lead to delayed embryonic development and hatching, decreased cardiac rate, and increased embryo malformation ratio (Gustin, 2003). Therefore, areas nearing the machine door (A1 and A2) were considered critical points regarding ambient temperature.

All sampled areas presented lower RH values than recommended in literature (Robertson, 1961; Lundy, 1969), ranging on 35.5 to $42.8 \%$ (Table 3). These lay below threshold for maximum hatchability (Wilson, 1991; French, 1997). Values of RH were not also homogeneously distributed in the incubator $(p<0.05)$. Certain areas had comparatively lower $\mathrm{RH}$ values (e.g. A3 and A4; Figure 1). Usually RH can vary more than DBT without depressing hatchability. Values of RH lower $\tan 50-60 \%$ may induce evaporative cooling and consequent reduced ambient temperature, which may embryo dehydration, increased incubation time, and consequent hatching depression or delay (Decuypere et al., 2003; Muraroli \& Mendes, 2003). Even though suitable incubation temperature values were found in areas A1, A2, A3, A5, and A6, embryos presented dehydration, and consequent hatching delay.

Wind speed inside the incubator was homogenous $(p<0.05)$. However, in areas A5 and A6 air speed reached only $4 \mathrm{~m} \mathrm{~s}^{-1}$, but reached $0.5 \mathrm{~m} \mathrm{~s}^{-1}$ in all others areas. The increase in wind speed facilitates heat loss by convection and leads to uneven temperature and that may negatively affect embryo development (Gustin, 2003).
Descriptive statistics of $\mathrm{CO}_{2}$ concentration inside the incubator is shown on Table 4. Eggs release different amounts of $\mathrm{CO}_{2}$ as incubation progresses (De Smit et al, 2006), and Onagbesan et al. (2007) points out that chicken embryos require $\mathrm{CO}_{2}$ at specific windows of development for enhanced growth and hatchability. However, fine tuning is required in the control of $\mathrm{CO}_{2}$ concentration in the incubator environment since decreased hatchability and increased embryonic abnormality have been reported as result of excess ambient $\mathrm{CO}_{2}$ concentration (Boleli, 2003). Carbon dioxide concentration levels were evenly distributed in all areas $(p<0.05)$ (Table 5); $\mathrm{CO}_{2}$ concentrations did not exceed $0.1 \%$ of the ambient air, indicating good ventilation and air renovation inside the incubator. In recent review about the role of gaseous exchange in egg incubation, Onagbesan et al. (2007) reported that $\mathrm{CO}_{2}$ concentration up to $1.5 \%$ during the first ten days of incubation enhance embryo growth and hatchability; and in the second half of the incubation period, environmental $\mathrm{CO}_{2}$ concentrations up to $4 \%$ do no affect hatchability or hatching time. Embryos are differently sensitive to both environmental $\mathrm{CO}_{2}$ and $\mathrm{O}_{2}$ with age. In this study, $\mathrm{CO}_{2}$ concentration values in all sampled areas of the incubator were positive for the first 10 days of incubation, but were low for the following incubation period.

Table 4 shows the descriptive statistics analysis related to fungi incidence. Areas A5 and A6 presented higher absolute values of fungi incidence in comparison to other areas, even though no differences were detected ( $p=0.239)$ (Table 5). However, since the mean fungi $\mathrm{CFU}$ number was equal or higher than 3.0 CFU, some degree of concern regarding the level of sanitary maintenance inside the hatchery house may be raised.

According to Sadler table (Table 1), which classifies air quality based on a mean number of fungi and bacteria (Tessari et al., 2002), results of this case study lay within air quality guidelines for the hatchery house, i.e., CFU values inside the incubator lower than $7 \mathrm{CFU}$. The presence of fungi in hatcheries house increase embryo's exposition to spores which may cause hyper sensibility reactions with damaging consequences to chick health. Even though there was an indication of overall good air quality, it is recommended developing efficient biosecurity and quality control program, that is controlling microorganisms proliferation at the critical points (areas A5 and A6) to reduce hazardous fungi influence on the environment (Kozak et al., 1979; Klanova, 2000). As a matter of fact, Marques (1986) report that some fungi found in hatcheries are known as responsible for low hatchability and embryo death (Lima et al., 2001; Vilar et al., 1995). Therefore, only constant monitoring of airborne microorganisms may ensure the one-day-old chicks health. 
Table 3 - Dry bulb temperature (DBT - $\left.{ }^{\circ} \mathrm{C}\right)$, relative humidity $(\mathrm{RH}-\%)$ : descriptive statistics for each sampled area in the incubator.

\begin{tabular}{|c|c|c|c|c|c|c|c|c|c|c|c|c|}
\hline & \multicolumn{2}{|c|}{ A1 } & \multicolumn{2}{|c|}{ A2 } & \multicolumn{2}{|c|}{ A3 } & \multicolumn{2}{|c|}{ A4 } & \multicolumn{2}{|c|}{ A5 } & \multicolumn{2}{|c|}{ A6 } \\
\hline & DBT & RH & DBT & $\mathrm{RH}$ & DBT & $\mathrm{RH}$ & DBT & $\mathrm{RH}$ & DBT & $\mathrm{RH}$ & DBT & RH \\
\hline Mean & 36.58 & 42.15 & 36.32 & 42.22 & 37.17 & 35.53 & 37.18 & 35.95 & 37.04 & 42.8 & 37.05 & 41.28 \\
\hline SE Mean & 0.1 & 1.69 & 0.1 & 1.56 & 0.06 & 1.27 & 0.06 & 1.07 & 0.02 & 1.52 & 0.02 & 1.87 \\
\hline St Dev & 0.34 & 5.85 & 0.34 & 5.61 & 0.18 & 3.8 & 0.19 & 3.55 & 0.07 & 5.87 & 0.08 & 6.98 \\
\hline
\end{tabular}

Table 4 - Carbon dioxide concentration $\left(\mathrm{mol} \mathrm{m}^{-3}\right)$ and fungi CFU distribution: descriptive statistics for each samped area in the incubator.

\begin{tabular}{|c|c|c|c|c|c|c|c|c|c|c|c|c|}
\hline & \multicolumn{2}{|c|}{$\mathrm{A} 1$} & \multicolumn{2}{|c|}{ A2 } & \multicolumn{2}{|c|}{$\mathrm{A} 3$} & \multicolumn{2}{|c|}{ A4 } & \multicolumn{2}{|c|}{ A5 } & \multicolumn{2}{|c|}{ A6 } \\
\hline & $\mathrm{CO}_{2}$ & CFU & $\mathrm{CO}_{2}$ & CFU & $\mathrm{CO}_{2}$ & CFU & $\mathrm{CO}_{2}$ & CFU & $\mathrm{CO}_{2}$ & CFU & $\mathrm{CO}_{2}$ & CFU \\
\hline Mean & 0.0280 & 1.17 & 0.031 & 1.50 & 0.031 & 1.33 & 0.031 & 1.67 & 0.0299 & 3.33 & 0.0299 & 3.00 \\
\hline SE Mean & 0.0039 & 0.44 & 0.0026 & 0.29 & 0.0026 & 0.44 & 0.0026 & 0.88 & 0.0299 & 0.73 & 0.0299 & 1.04 \\
\hline St Dev & 0.0068 & 0.76 & 0.00448 & 0.50 & 0.00448 & 0.76 & 0.00448 & 1.53 & 0.0052 & 1.26 & 0.0052 & 1.80 \\
\hline
\end{tabular}

Table 5 - Kruskal-Wallis non-parametric test to dry bulb temperature (DBT - $\left.{ }^{\circ} \mathrm{C}\right)$, relative humidity $(\mathrm{RH}-\%)$, carbon dioxide concentration $\left(\mathrm{mol} \mathrm{m}^{-3}\right)$, and CFU: comparison of incidence distributions inside the sampled areas of incubator.

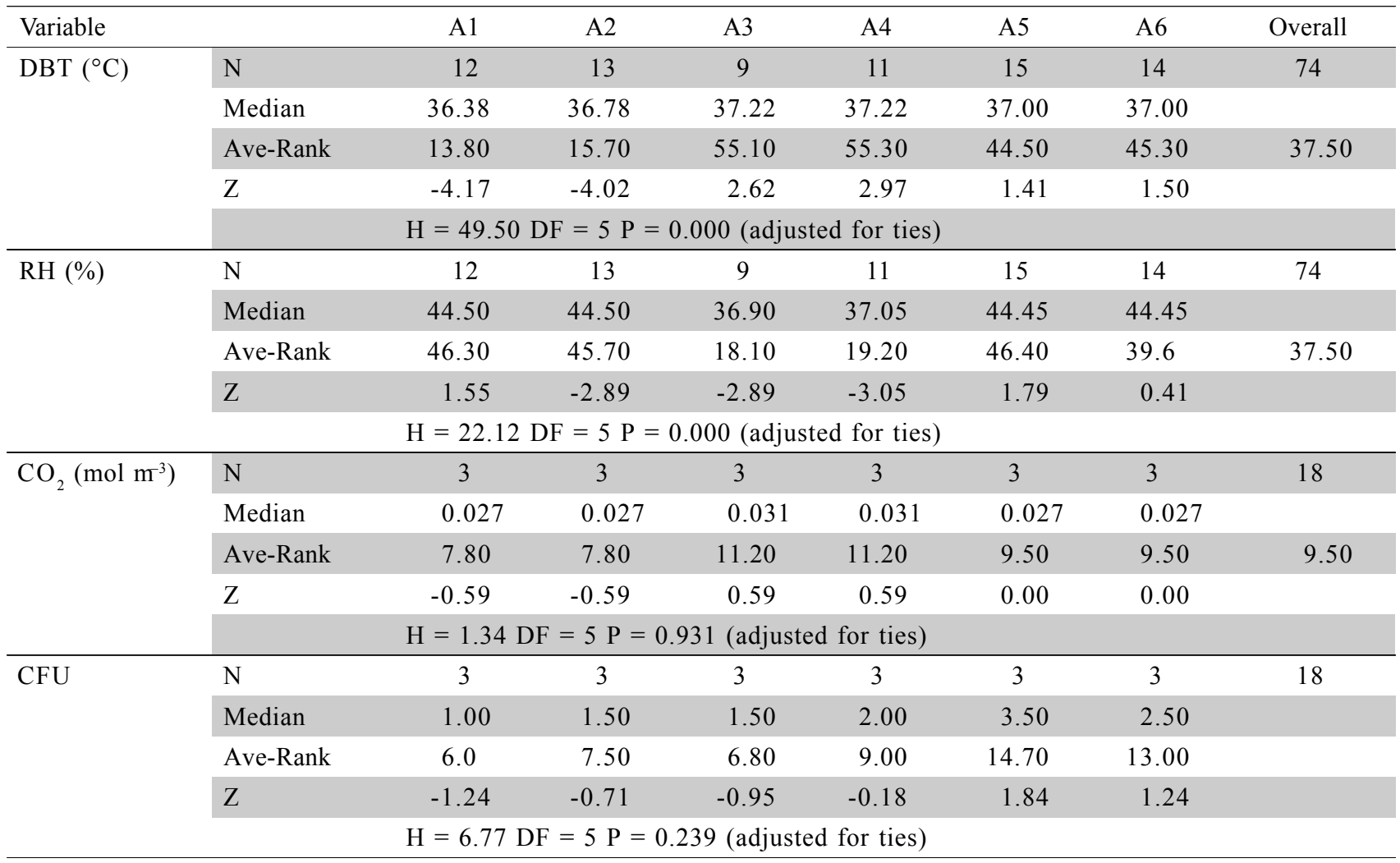

Recorded CFU values (from 3 to 5 in A5 and A6) were similar to those reported by Berrang et al. (1997), who compared effects of different egg sanitation practices prior to incubation and found crosscontamination in sanitized and non-sanitized eggs coming from five different farms. However, air circulation may not have caused cross-contamination of eggs in this study, since environmental temperature remained constant in areas A5 and A6, indicating low heat exchange in the specific areas probably because oflack of ventilation; adopted disinfection management seemingly thus needs improvement (Lima et al., 2001).

Table 6 summarizes the thermal and aerial environment inside the incubator, shows the current recommended values for reaching the best hatchability, and contrasts one day-old chick quality with values of 
Table 6 - Optimum environmental condition for broiler incubation versus actual environmental condition and critical points on multi-stage setter.

\begin{tabular}{lcc}
\hline & Environment recommended values for broiler egg incubation & Identified Critical Points \\
\hline Temperature $\left({ }^{\circ} \mathrm{C}\right)$ & $37-38^{\circ} \mathrm{C}$ & A1 and A2 $\left(<37^{\circ} \mathrm{C}\right)$ \\
$\mathrm{RH}(\%)$ & $50 \%-60 \%$ & All areas mainly in A3 and A4 \\
$\mathrm{CFU}$ & $0-3 \mathrm{CFU}$ mean value & A5 and A6 \\
\hline
\end{tabular}

each analyzed variable recorded for identified critical points. All sampled areas inside the incubator were classified as critical points regarding at least one analyzed variable. Technological innovations of multi setter incubation system are in order, as suitable machine adjustment and control for embryo requirements during their different development stage need to be provided.

\section{ACKNOWLEDGEMENTS}

To FAPESP and CNPq for the financial support.

\section{REFERENCES}

ALDA, T.R.B.L. Embrio-diagnóstico. In: MACARI, M.; GONZALES, E. Manejo da incubação. Campinas: FACTA, 2003. p.499-514.

BERRANG, M.E.; FRANK, J.F.; BUHR, R.J.; BAILEY, J.S.; COX, N.A.; MAULDIN, J.M. Microbiology of sanitized broiler hatching egg through the egg production period. Journal of Applied Poultry Research, v.6, p.298-305, 1997.

BOERJAN, M.L. Incubação em estágio único para melhorar a uniformidade. In: CONFERÊNCIA APINCO DE CIÊNCIA E TECNOLOGIA AVÍCOLAS, Santos, 2006. Anais. Campinas: FACTA, 2006. v.1, p.325-333.

BOLELI, I.C. Estresse, mortalidade e malformações embrionárias. In: MACARI, M.; GONZALES, E. Manejo da incubação. Campinas: FACTA, 2003. p.472-498.

BRAMWELL, R.K. Egg shell mottling and hatchability. 2002. Available at: http://www.thepoultrysite.com/FeaturedArticle/ FATopic.asp?AREA=Incubation\&Display $=28$. Accessed 4 Jan 2007.

DE SMIT, L.; BRUGGEMAN, V.; TONA, J.K.; DEBONNE, M.; ONAGBESAN, O.; ARCKENS, L.; DE BAERDEMAEKER, J.; DECUYPERE, E. Embryonic developmental plasticity of the chicken: increased $\mathrm{CO}_{2}$ during early stages of incubation changes the developmental trajectories during prenatal and postnatal growth. Comparative Biochemistry and Physiology -Part A, v.145, p.166-175, 2006.

DECUYPERE, E.; MALHEIROS, R.D.; MORAES, V.M.B.; BRUGGEMAN, V. Fisiologia do embrião. In: MACARI, M.; GONZALES, E. Manejo da incubação. Campinas: FACTA, 2003. p.65-94.

DECUYPERE, E.; MICHELS, H. Incubation temperature as a management tool: a review. World's Poultry Science Journal, v.48, p.28-38, 1992.

FRENCH, N.A. Modeling incubation temperature: the effects of incubator design, embryonic development, and egg size. Poultry Science, v.76, p.124-133, 1997.

GUSTIN, P.C. Biossegurança no incubatório. In: MACARI, M.; GONZALES, E. Manejo da Incubação. Campinas: FACTA, 2003. p.297-352.

KLANOVA, K. The concentrations of mixed populations of fungi in indoor air: rooms with and without mould problems; rooms with and without health complaints. Central European Journal of Public Health, v.8, p.59-61, 2000.
KOZAK, P.P.; GALLUP, J.; CUMMINS, L.H.; GILLMAN, S.A. Factors of importance in determining the prevalence of indoor molds. Annals of Allergy, v.43, p.88-94, 1979.

LIMA, J.S.J.; PINTO, D.M.; CARRASCO, L.O.; SALGUERO, F.J.B., MEIRELES, M.A. Incidência de fungos na produção de pintos corte de um dia de idade. Revista Brasileira de Agrociência, v.7, p.73-77, 2001.

LUNDY, H. A review of the effects of temperature, humidity, turning and gaseous environment in the incubator on hatchability of hen's eggs. In: CARTER, T.C.; FREEMAN, B.M. The fertility and hatchability of the hen's egg. Edinburg: Oliver and Boyd, 1969. 231p.

MARQUES, D. Manual do incubador. Amparo: CASP, 1986. $214 p$.

MINITAB. Minitab 15.1.0.0. State College: Minitab Inc., 2006. MISSISSIPI STATE UNIVERSITY EXTENTION SERVICE - MSU. Important incubation factors. 2004. Available at: http:// www.thepoultrysite.com/articles/151/important-incubationfactors. Accessed 7 Mar. 2007.

MURAROLI, A.; MENDES, A.A. Manejo da incubação, transferência e nascimento do pinto. In: MACARI, M.; GONZALES, E. Manejo da incubação. Campinas: FACTA, 2003. p. 180-198.

ONAGBESAN, O.; BRUGGEMAN, L.; DE SMIT, L.; DEBONNE, M.; WITTERS, A.; TONA, K.; EVERAERT, N.; DECUYPERE, E. Gas exchange during storage and incubation of avian eggs: effects on embryogenesis, hatchability, chick quality and post hatch growth. World's Poultry Science Journal, v.63, p.557573, 2007.

PONTECORVO, G.; ROPER, J.A.; HEMMONS, D.W.; MacDONALD, K.D.; BUFTON, A.W. The genetics of Aspergillus nidulans. Advances in Genetics, v.5, p.141-238, 1953.

ROBERTSON, I.S. Studies in the effect of humidity on the hatchability of hen's eggs. I. The determination of optimum humidity for incubation. Journal of Agricultural Sciences, v. 57, p.185-194, 1961

SILVEIRA, V.D. Lições de micologia. 3 ed. Rio de Janeiro: José Olympio, 1968. 301p.

TESSARI, E.N.C.; CARDOSO, A.L.S.P.; CASTRO, A.G.M.; KANASHIRO, A.M.I.; ZANATTA, G.F. Avaliação das condições sanitárias de incubatório de pintos de corte. Arquivos do Instituto Biológico, v.69, p.1-4, 2002.

USDA. Brazil: Poultry and Products; Annual Poultry Report. Washington, D.C.: USDA/FAS, 2005. 15p. (GAIN Report, BR5620).

VILAR, E.A.; VILELA, S.M.O.; SAUKAS, T.N. Infecção de Embriões de Codornas (Coturnix coturnix japonica) por Aspergillus sp. e Penicillium sp. In: CONFERÊNCIA DA APINCO DE CIÊNCIA E TECNOLOGIA AVÍCOLAS. Campinas, 1995. Anais. Campinas: Fundação APINCO, 1995. p.143-144.

WILSON, H.R. Physiological requirements of the developing embryo: temperature and turning. In: TULLET, S.G. Avian incubation. Northampton: Butterworth-Heinemann, 1991. p. $145-156$.

Received May 30, 2007

Accepted August 29, 2008 